\title{
PERJURED TESTIMONY: ITS EFFECT ON CRIMINAL DEFENDANTS' CONSTITUTIONAL RIGHTS
}

T

HE extent to which perjured testimony effectively denies to a defendant the fair trial guaranteed to him by the fourteenth amendment was, until recently, apparently well established by the rule of Mooney v. Holahan. ' There it was held that a new trial was constitutionally required where conviction had been obtained by the presentation of testimony known to the prosecution authorities to have been perjured. ${ }^{2}$ While the language of subsequent decisions purporting to follow this rule has remained deceptively similar, ${ }^{3}$ and an express confinement of the definition of the term "prosecution authorities" has been noticeably absent, the rule has, nevertheless, undergone subtle, unarticulated changes.

That this revision has gone unnoticed by most courts and, therefore, resulted in unnecessary confusion is aptly illustrated by the recent case of Curran v. State. There, a high ranking police officer, without the knowledge of the prosecuting attorneys, perjured himself in contradicting the defendants' testimony. The Supreme Court of Delaware held that the defendants were not thereby deprived of a fair trial and interpreted the Mooney rule to require that perjury, in order to constitute a denial of due process, must be "brought home to the prosecuting

\footnotetext{
${ }_{294}$ U.S. 103 (1935).

$A$ second and complementary rule followed in many jurisdictions affords a defendant a new trial where the reviewing court is reasonably certain that testimony of a material witness is false; that, without it, the jury might have reached a different conclusion; that the defendant was taken by surprise with the false testimony and was unable to meet it or did not know of its falsity until after the trial. See, for example, Larrison ø. United States, 24 F.2d 82, 87 (x928). Reference to this rule, although it is not based upon constitutional principles, is necessary to portray adequately the picture with regard to injurious perjnred testimony and to place the rule of Mooney v. Holohan in its proper perspective.

${ }^{2}$ While this rule is attributed to Mooney $v$. Holohan, in reality it has grown from a principle announced in that case as mere dictum. Although the language of that dictum was broad, the fact the allegations accused the prosecutor, individually, of surpressing important evidence is the basis for the formulation of the rule.

- Use of the same words in formulating the rule without further explanation has created situations in which it is virtually impossible to detect substantive changes which may have existed in the minds of some judges. Yet, recent cases indicate that behind this façade of repetition changes must have transpired.

49 Del. 587, 122 A.2d 226 (1956).
} 
officer."' Defendants successfully petitioned the federal diștrict court for a writ of habeas corpus on the ground that such perjury constituted a "fundamental unfairness in the trial of a criminal case." This decision, unique in that it marks the first time a court has explained, without equivocation, that the Mooney rule extends to state agents other than the prosecuting attorneys, suggests that a close reappraisal of that doctrine is necessary.

Fundamental to the application of the Mooney rule is the advertent use of material perjured testimony by state authorities. For only in this manner is the defendant deprived, by state action, of his constitutional right to a fair trial. It is not clear, however, why most courts have restricted application of Mooney $v$. Holahan to a single type of state agent, the prosecuting attorney. ${ }^{7}$ Apparently, this result flows in large measure from the fact that a vast majority of the cases has involved knowledge of perjury by this official and, consequently, has permitted -even encouraged-a mechanical application of the rule. ${ }^{8}$ This maze of

${ }^{5} 49$ Del. 587, 595, 122 A.2d 126, 130 (1956).

154 F. Supp. 27, 31 (D. Del. 1957).

${ }^{7}$ See, for example: White v. Ragen, 324 U.S. 760 (1945); New York ex rel. Whitman v. Wilson, 318 U.S. 688 (1943); Lisenba v. California, 314 U.S. 219 (1941); Taylor v. United States, 221 F.2d 228 (9th Cir: 1955); United States ex rel. House v. Swope, 219 F.2d 538 (5th Cir. 1955); Ryles v. United States, 198 F.2d 199 (roth Cir. 1952); Story v. Burford, 178 F.2d 91 I (roth Cir. 1949); James v. United States, 175 F.2d 769 (5th Cir. 1949); United States ex. rel. Rooney v. Ragen, I73 F.2d 668 (7th Cir. 1948); Cobb v. United States, 161 F.2d 814 (6th Cir. r 947); Wagner v. Hunter, 16r F.2d 601 (roth Cir. 1947); Casebeer v. Hudspeth, 121 F.2d 914 (10th Cir. 1941); United States $e x$ rel. Bevilacqua v. Reincke, 147 F. Supp. 933 (D. Conn. 1956); United States v. Sobell, 142 F. Supp. 515 (S.D.N.Y. 1956); Hubbard v. Jacques, 95 F. Supp. 894 (W.D. Mich. 195I); Kowalak v Frisbie, 93 F. Supp. 777 (E.D. Mich. 1950); United States ex rel. Montgomery v. Ragen, 86 F. Supp. 382 (N.D. Ill. 1949); Wilhoit v. Hiatt, 6o F. Supp. 664 (M.D. Pa. 1945); People ex rel. Albanese v. Hunt, 34 F. Supp. 444 (W.D.N.Y. 1939) ; Hurt v. State, 312 P.2d 169 (Okla. Crim. 1957); Commonwealth ex. rel. Cobb v. Burke, 176 Pa. Super. 60, 107 A.2d 207. (r954); Aronson v. Commonwealth, 33I Mass. 599, I 21 N.E.2d 669 (1954); Smyth v. Godwin, I88 Va. 753, 51 S.E.2d 230 (1949); People v. Whitman, 56 N.Y.S.2d 890 (1945); Dolan v. State, 195 Miss. I54, 13 So.2d 925 (1943); Ex parte Wallace, 24 Cal.2d 933, 152 P.2d I (1944).

It will be noted that many of the cases cited herein involve federal as well as state action. Although the scope of this note is limited to state action, the federal action cases are pertinent authority in that they are often cited inerchangeably with state action cases by the courts.

Since the Mooney rule requires that the prosecution authorities know that perjured testimony was used against the defendant, those defendants asserting it generally allege participation by the prosecutor. The result is a process confusingly circuitous in that the more typical the case the more firmly entrenched becomes the rule, and as the rule becomes less flexible so the case arising under it becomes more stereotyped. 
stereotyped cases may, in turn, have induced many other courts, faced with situations involving other state officials, to ignore the broader ramifications of the rule.

Some courts, however, have not felt constrained to accept a narrow interpretation of the Mooney rule, and, by expanding the meaning of the word "prosecution" or by rejecting its limiting implication completely, those courts have.construed the rule to embrace state agents other than prosecuting attorneys. ${ }^{9}$ The first of these cases was Pyle $v$. Kanses, ${ }^{10}$ where the uncontroverted allegations made no mention of the prosecuting attorney's knowledge but stated that the ". . . affiant was forced to give perjured testimony ... by local authorities . . . and the Kansas State Police. . . ." The Supreme Court of the United States applied the Mooney doctrine to condemn this action. While a number of courts, subsequently faced with the stereotyped ${ }^{11}$ fact situation, have cited the Pyle decision, or have aligned themselves with the reasoning therein, in support of their conclusions, ${ }^{12}$ there is some question as to

- In ex parte Lindey, 29 Cal.2d· 709, 177 P.2d 918, 926 (1947) it is significant that no reference to the terms "prosecutor" or "prosecution" is made, the majority of the court sajing that where conviction is obtained ". . . by perjured testimony knowingly presented by representatives of the State, (the defendant) is entitled to a judgment discharging him from custody and the suppression by the State of material evidence will be considered in connection with such a charge." Three concurring justices preferred limiting the rule to responsible representatives of the state. In In re $\mathrm{De} \mathrm{La}$ Roi, 28 Cal.2d 264, 169 P.2d 363, 366, 367, 370 (1946) whereas the court spoke of "prosecuting officials," it also used the broader terms, "representative of the state of California" and "any officer or officers." Note also the progression in the following seven Maryland cases beginning with Reeder v. Warden, $196 \mathrm{Md} .683,77$ A.2d I (1950) in which the court seemed purposely to avoid using the words "prosecution" or "prosecutor." To the same effect are Johns v. Warden, 205 Md. 644, 108 A.2d 906 (1954) and State ex rel. Billman v. Warden, 197 Md. 683, 79 A.2d 540 (1951), the latter court saying, "There is no charge that any state officer or employee had any part in procuring such perjury . . . or knew that the testimony was perjured." But in Madison v. State, 205 Md. 425, 109 A.2d 96 (1954), typical fact situations, the courts reverted to such orthodox language as "prosecution," "prosecuting authorities," and "prosecuting attorney." However, in view of the fact that these cases relied on the earlier broader cases and that the subsequent cases of Barker v. Warden, 208 Md. 662, 119 A.2d 710 (1956), Brigmon v. Warden, 213 Md. 628, 131 A.2d 245 (1957) and MćCutheon v. Warden, 138 A.2d 369 (Md. 1958) returned to more liberal langnage ("state's officers"), it can be said that these seven decisions reflect an extension of the Moortey rule.

See also Jones $\dot{v}$. Commonwealth, 97 F.2d 335 (6th Cir. 1938), which seemingly set forth a rule broader than any before or since the Mooney case.

${ }^{10} 317$ U.S. 213 (1942).

${ }^{21}$ That is to say, cases in which the alleged evil concerns the prosecuting attorney as opposed to any other governmental official.:

${ }^{11}$ Lister v. McLeod, 240 F.2d 1.6 (roth Cir. 1957); Bales v. Larrison, 244 F.2d 
whether these courts have adopted that decision in its broadest aspects or whether they are blind to other than its most salient implications. ${ }^{13}$ Other cases, too, have contained language that appears to depart from the narrow construction of the Mooney rule but which may, in reality, rather have been intended only as a slightly different wording of the same general rule. ${ }^{14}$

495 (8th Cir. 1957); United States v. Rutkin, 2 I2 F.2d 641 (3d Cir. 1954); United States ex. rel. O'Connell v. Ragen, 212 F.2d 272 (7th Cir. 1954); United States v. Spadafora, 200 F.2d r4o (7th Cir. 1952); United States ex rel. Almeida v. Baldi, r 95 F.2d 8 I5 (3d Cir. 1952); United States v. Rosenberg, ro8 F. Supp. 798 (S.D.N.Y. 1952); Brigmon v. Warden, 2 I 3 Md. 35, I3 I A.2d 245 (1957); Edwards v. People, 76 S.Ct. 1058 (1956); State v. Eaton, 280 S.W.2d 63 (Mo. 1955); France v. Warden, 205 Md. 636, rog A.2d 65 (1954); Madison v. State, 205 Md. 425, rog A.2d 96 (r954); Johns v. Warden, 205 Md. 644, 108 A.2d 906 (1954); State ex rel. Billman v. Warden, I97 Md. 683, 79 A.2d 540 (195I) ; Reeder .v. Warden, r96 Md. 683, 77 A.2d I (1950); Townsend v. Hudspeth, I67 Kan. 366, 205 P.2d 483 (1949); Burke v. State, 205 Ga. 656, 54 S.E.2d 350 (1949); Pyle v. Amrine, I59 Kan. 458, I56 P.2d 509 (1945); Ex parte Burns, 247 Ala. 98, .22 So.2d 517 (1945); Morhous v. Supreme Court of New York, 293 N.Y. 13 1, 56 N.E.2d 79 .( (1944); Anderson v. Buchanan, 292 Ky. 810, I68 S.W.2d 48 (1943).

${ }^{13}$ Exemplary of such a misconception is Pyle v. Amrine, I59 Kan. 458, I56 P.2d 509, 515 (1945), the follow-up case to Pyle v. Kansas, 3 I7 U.S. 2 I3 (I942). There the Kansas court interpreted.Pyle v. Kansas to mean that "in order to constitute grounds for release on a writ of habeas corpus it inust appear that the officers in charge of the prosecution knew it to be false." If any ambiguity remained after that decision it vanished when, four years later, the same Kansas court cited Pyle v. Amrine to stand for the proposition that the prosecutor inust know of the perjury. Townsend v. Hudspeth, 167 Kan. 366, 205 P.2d 483 (r949). Thus, if Pyle v. Kansas had extended the rule it went unnoticed by the very court directly affected by it.

Is In Hysler v. Florida, 3 IS U.S. 4II (I942) the United States Supreine Court said, ". . . if Florida, through her responsible officials knowingly used false testimony . . : extorted from a witness by violence and torture'. . . [then] convicted [defendant] may clain protection of the Due Process Clause. . . ." Id. at 4r3. And while this appears to extend the Mooney rule, the implication is that the inajority ineant the prosecuting attorney. In addition, the dissent stated, "T do not, however, regard this as a proper occasion to determine whether the rule of Mooney v. Holohan applies only where guilty knowledge is that of 'the prosecuting officer' and not any other responsible official." Id. at 423 . Other cases present similar ambiguities: "neither the United States nor any of its officers," and, "prosecuting authorities," United States v. Jakalski, 237 F.2d 503, 504, 505 (7th Cir. 1956); "prosecuting attorney or anyone else connected with the Government," Owens v. Hunter, I69 F.2d 97x, 972 (roth Cir. I948); "officials connected with trial in the state court," Tompsett v. State, 146 F.2d 95, 99 (6th Cir. I944); "state," "prosecuting authorities," "prosecuting attorneys," Petition of Sawyer, 129 F. Supp. 687,696 (D. Wis. I955); "false testimony ... used by the State at the trial with knowledge that it was perjured testimony," Caldwell v. State, 36 Ala. 612, 63 So.2d 384, 385 (1952); Exp parte Gammon, 255 Ala. 502 , 52 So.2d 369 (195 I); "the agencies of the state for the enforcement of law and administration of justice. . .," Skipper v. Schumacher, I24 Fla. 384,169 So. 58, 64 (1936). 
Nevertheless, the customary narrow construction of Mooney v. Holahan is apparently relaxing, and new limitations will, of necessity, have to be formulated. A workable solution might be to expand the meaning of the term "prosecution authorities" to include all employees of the state directly connected with bringing a particular defendant to justice, rather than to disturb the language of the general rule. This would permit judicial flexibility and would more nearly afford the defendant the protection against prejudicial state action, to which he is constitutionally entitled. 